\title{
LITERASI DIGITAL DALAM PEMBELAJARAN DARING
}

\author{
${ }^{1}$ Karsoni Berta Dinata \\ ${ }^{1}$ karsoni.bertadinata@gmail.com
}

\section{${ }^{1}$ Universitas Muhammadiyah Kotabumi}

\begin{abstract}
The success of online learning is determined by several aspects, namely aspects of facilities and infrastructure as well as aspects of the ability of lecturers and students in organizing online learning. This article aims to examine the role of digital literacy in online learning. Based on the results of the study, it can be concluded that digital literacy skills have an important role in online learning. Students with good digital literacy skills will strive to find and select important information and understand, communicate, and convey ideas in the digital space. In addition, digital literacy skills will open opportunities for students to think, communicate, and work which ultimately leads to student learning success.
\end{abstract}

\section{Keyword: digital literacy, E-Learning, Covid 19.}

Abstrak: Keberhasilan pembelajaran daring ditentukan oleh beberapa aspek yaitu aspek sarana dan prasarana serta aspek kemampuan dosen dan mahasiswa dalam menyelenggarakan pembelajaran daring. Artikel ini bertujuan untuk mengkaji bagaimana peranan literasi digital dalam pembelajaran daring. Berdasarkan hasil kajian, dapat disimpulkan bahwa kemampuan literasi digital berperan penting dalam menunjang keberhasilan pembelajaran daring. mahasiswa dengan kemampuan literasi digital yang baik akan berupaya untuk mencari dan menyeleksi informasi yang penting dan memahami, mengkomunikasikan, dan menyampaikan gagasan-gasan dalam ruang digital. Selain itu, kemampuan literasi digital akan membuka kesempatan kepada mahasiswa untuk berpikir, berkomunikasi, dan berkarya yang akhirnya bermuara pada kesuksesan belajar mahasiswa.

Kata Kunci: literasi digital, pembelajaran daring, covid 19

\section{A. PENDAHULUAN}

Pandemi covid-19 menyebabkan perubahan proses pembelajaran dari pembelajaran tatap muka langsung menjadi pembelajaran daring. Perubahan tersebut mengakibatkan munculnya berbagai problematika. Tentu saja, problematika suatu pembelajaran perlu dicarikan solusi dan perlu adanya upaya untuk senantiasa meningkatkan mutu pembelajaran (Dinata, 2020) Pergeseran proses pembelajaran menjadi pembelajaran daring, menuntut dosen dan mahasiswa terbiasa dengan pembelajaran daring.

Keberhasilan pembelajaran daring ditentukan oleh beberapa aspek yaitu aspek sarana dan prasarana serta aspek kemampuan dosen dan mahasiswa dalam 
menyelenggarakan pembelajaran daring. Aspek sarana dan prasarana yang diperlukan dalam pembelajaran daring yaitu perangkat keras pembelajaran daring seperti komputer, laptop, atau smartphone; sinyal/wifi; tentu saja aplikasi yang diperlukan dalam pembelajaran daring seperti zoom, whatsapp, gmail, google classroom, dan lain-lain.

Kemampuan dosen dan mahasiswa dalam menyelenggarakan pembelajaran daring sangat menentukan dalam keberhasilan pembelajaran daring. Inovasi suatu pembelajaran sangat bergantung dengan kreativitas pendidik/dosen (Dinata, 2018) Beberapa kemampuan yang diperlukan yaitu kemampuan menggunakan komputer/smartphone, memanfaatkan internet, kretivitas dalam menyelenggarakan pembelajaran daring, kemampuan kolaborasi, dan kemampuan dalam memilih serta memanfaatkan informasi. Kemampuan yang telah disebutkan tersebut disebut dengan kemampuan literasi digital. Dengan demikian kemampuan literasi digital memainkan peranan yang sangat strategis dalam menentukan keberhasilan pembelajaran daring.

Artikel ini bertujuan untuk mengkaji bagaimana peranan literasi digital dalam pembelajaran daring. Kajian akan difokuskan pada kajian deskriptif peran literasi digital dalam pembelajaran daring, serta akan diperkuat dengan penelitian yang relevan.

\section{A. KAJIAN TEORI}

\section{Pembelajaran}

Pembelajaran mempunyai kata dasar yaitu belajar. Dalam kamus besar bahasa indonesia, belajar secara bahasa diartikan sebagai suatu usaha untuk memperoleh kepandaiaan atau ilmu, berlatih, berubah tingkah laku atau tanggapan yang disebabkan oleh pengalaman. Gagne (1977) menyatakan bahwa "belajar terjadi apabila suatu stimulus bersama dengan isi ingatan mempengaruhi siswa sedemikian rupa sehingga perbuatannya berubah dari waktu sebelum ia mengalami situasi itu ke waktu sesudah ia mengalami situasi tadi”. Morgan (Dalam Ratumanan, 2004) menyatakan bahwa "belajar adalah setiap perubahan yang relatif menetap dalam tingkah laku yang terjadi sebagai suatu hasil dari latihan atau pengalaman". Berdasarkan pendapat kedua ahli tersebut dapat disimpulkan bahwa belajar merupakan perubahan yang relatif menetap dalam tingkah laku atau perbuatan sebagai akibat dari suatu stimulus atau hasil dari latihan atau pengalaman. Perubahan yang dimaksud 
disini tidak hanya perubahan tingkah laku, tetapi juga tentang sikap dan kognitif.

Upaya yang dilakukan oleh pendidik/dosen untuk membantu seseorang agar dapat memperoleh pengetahuan, skill, dan sikap disebut dengan pembelajaran. Gagne (1977) menyatakan bahwa pembelajaran adalah "seperangkat peristiwa-peristiwa eksternal yang dirancang untuk mendukung beberapa proses belajar yang bersifat internal". Lebih lanjut, Gagne (1985) mengemukakan bahwa "pembelajaran dimaksudkan untuk menghasilkan belajar, situasi eksternal harus dirancang sedemikian rupa untuk mengaktifkan, mendukung, dan mempertahankan proses internal yang terdapat dalam setiap peristiwa belajar". Hardini dan Puspitasari (2012:10). "Pembelajaran adalah suatu aktivitas yang dengan sengaja untuk memodifikasi berbagai kondisi yang diarahkan untuk tercapainya suatu tujuan, yaitu tercapainya tujuan kurikulum”. Dengan demikian dapat disimpulkan bahwa pembelajaran merupakan proses interaksi peserta didik dengan pendidik dan sumber belajar pada suatu lingkungan belajar.

Berdasarkan definisi pembelajaran dapat dikatakan bahwa suatu pembelajaran akan terlaksana jika terdapat dua faktor yaitu 1) adanya interaksi antara pendidik dengan peserta didik dan 2) adanya sumber belajar. Interaksi antara pendidik dengan peserta didik dapat terjadi secara tatap muka langsung atau secara virtual melalui suatu flatform tertentu seperti zoom, google meet, dan lain-lain. Sumber belajar dapat berupa buku, modul, diktat, internet, dan lain lain. Sumber belajar yang baik adalah yang sesuai dengan karakteristik peserta didik. Oleh karena itu pengembangan bahan ajar perlu dilakukan oleh pendidik (Dinata et al, 2020). Oleh karena itu, saat wabah pandemi yang mengharuskan adanya pembatasan sosial, pembelajaran akan tetap dapat dilangsungkan secara virtual dengan menggunakan berbagai flatform. Hal yang perlu digarisbawahi adalah pembelajaran secara virtual atau daring mengharuskan adanya interaksi antara pendidik dan peserta didik dengan suatu sumber belajar. Interaksi yang diharapkan tentu saja adalah interaksi timbal balik. Pembelajaran baik daring atau tatap muka langsung harus ditujukan pada pengembangan kognitif, afektif dan psikomotor (Dinata, 2019)

Baik pembelajaran tatap muka langsung dengan pembelajaran daring masing-masing memiliki kelebihan dan kekurangan. Adapun kelebihan dan kekurangan pembelajaran daring dengan pembelajaran tatap muka langsung dapat dilihat pada Tabel 1 berikut. 
Tabel 1 Kelebihan dan kekurangan

Pembelajarang Daring dan Tatap Muka langsung

\begin{tabular}{cl}
$\begin{array}{c}\text { Pembelajaran } \\
\text { tatap muka } \\
\text { langsung }\end{array}$ & $\begin{array}{l}\text { Pembelajara } \\
\text { n daring }\end{array}$ \\
\hline
\end{tabular}

\begin{tabular}{llll}
\hline Keleb & 1. & Respon balik & 1. Pembelajar \\
ihan & yang cepat. & an terpusat \\
& 2. Sudah menjadi & dan melatih \\
& sesuatu yang & kemandiria \\
familiar bagi & n. \\
pengajar dan & 2. Biaya \\
& murid. & terjangkau \\
& 3. Memotifasi & untuk para \\
& Pelajar & peserta. \\
4. Penanaman jiwa & 3. Akses yang \\
sosial dengan & tidak \\
& lingkungan & terbatas \\
& sekitar. & dalam \\
& & perkemban \\
& gan \\
& & pengetahua \\
\end{tabular}

\begin{tabular}{|c|c|c|}
\hline $\begin{array}{l}\text { Keku } \\
\text { ranga } \\
\text { n }\end{array}$ & $\begin{array}{l}\text { 1. } \text { Terlalu } \\
\text { bergantung } \\
\text { kepada pengajar } \\
\text { 2. Terbatas oleh } \\
\text { waktu dan } \\
\text { lokasi } \\
\text { 3. Semakin har } \\
\text { biaya } \\
\text { pembelajaran } \\
\text { semakin mahal }\end{array}$ & $\begin{array}{l}\text { 1. Kurang } \\
\text { cepatnya } \\
\text { umpan } \\
\text { balik yang } \\
\text { dibutuhkan } \\
\text { dalam } \\
\text { proses } \\
\text { belajar } \\
\text { mengajar } \\
\text { 2. Pengajar } \\
\text { perlu waktu } \\
\text { lebih lama } \\
\text { untuk } \\
\text { mempersia } \\
\text { pkan diri } \\
\text { 3. Terkadang } \\
\text { membuat } \\
\text { beberapa } \\
\text { orang } \\
\text { merasa } \\
\text { tidak } \\
\text { nyaman } \\
\text { 4. Adanya } \\
\text { kemungkin } \\
\text { an muncul } \\
\text { perilaku }\end{array}$ \\
\hline
\end{tabular}

\begin{tabular}{ll}
\hline & frustasi, \\
kecemasan, \\
dan \\
kebingunga \\
$\mathrm{n}$ \\
\hline
\end{tabular}

Keberhasilan pelaksanaan pembelajaran daring sangat tergantung dengan faktor pendukung dan penghambatnya. Penelitian yang dilakukan oleh Putria et al (2020) menyimpulkan bahwa "Ada beberapa faktor pendukung guru dalam proses pembelajaran daring yaitu ketersediannya handphone, kuota dan jaringan internet yang stabil. Selain adanya faktor yang mendukung dalam pembelajaran daring terdapat juga beberapa faktor penghambat guru dalam pembelajaran daring. Faktor penghambat tersebut diantaranya adalah belum semua peserta didik memiliki handphone dan masih banyak orang tua sibuk bekerja". Sejalan dengan itu, hasil penelitian yang dilakukan oleh Pangondian \& Santosa (2019) menyatkan bahwa faktor pendukung dari pembelajaran daring yaitu tutor yang berkompeten dan Sarana dan Prasarana pembelajaran daring. Dengan demikian berdasarkan kedua hasil penelitian tersebut dapat dikatan bahwa faktor pendukung dan penghambat suatu pembelajaran daring sangat ditentukan dari kompetensi pendidik/guru/tutor dan peserta didik, serta ketersediaan sarana dan prasarana pembelajaran daring yang meliputi 
Jurnal Eksponen, Vol. 11 No. 1, April 2021

ketersediaan smartphone/komputer,

bentuk pembelajaran dari pembelajaran Kuota/wifi, dan kekuatan sinyal.

Berdasarkan hasil beberapa tatap muka langsung menjadi pembelajaran daring. Hal ini tentu saja menuntut penelitian mengenai penerapan pembelajaran daring, dapat disimpulkan bahwa pembelajaran daring saat ini masih perlu untuk diperbaiki (Kuntarto, 2017) (Dinata, 2020).

\section{Literasi Digital}

Dunia saat ini sedang berada dimasa revolusi industri 4.0. Menurut Risdianto (2019) "beberapa ciri dari revolusi industri 4.0 adalah internet of thing yaitu kecepatan yang dikendalikan oleh internet. Saat ini semua pekerjaan hampir semua terhubung dengan koneksi internet. Ciri selanjutnya adalah big data. Pernahkah kita disodori oleh iklan mengenai barang barang kesukaan kita? Bagaimana sistem itu tahu karena terdapat sebuah data yang mengkoleksi informasi kita".

Beberapa orang menyebut revolusi indutri 4.0 sebagai revolusi digital dan era disrupsi. Menurut Kasali (2018) "pada era ini teknologi informasi telah menjadi basis atau dasar dalam kehidupan manusia. Dampak yang sangat terasa dari era digital adalah berlimpahnya sumber informasi yang dapat diakses secara tidak terbatas".

Selain itu juga, dunia saat ini masih dilanda pandemi covid-19. Akibat dari pandemi ini adalah terjadinya perubahan mahasiswa dan dosen harus siap dengan perubahan tersebut.

Salah satu kemampuan yang harus dimiliki oleh dosen dan mahasiswa dalam rangka menghadapi era revolusi digital dan pandemi covid-19 adalah kemampuan Literasi Digital.

Menurut Paul Gilster dalam bukunya yang berjudul Digital Literacy (1997), literasi digital diartikan "sebagai kemampuan untuk memahami dan menggunakan informasi dalam berbagai bentuk dari berbagai sumber yang sangat luas yang diakses melalui piranti komputer".

Bawden (2001) "menawarkan pemahaman baru mengenai literasi digital yang berakar pada literasi komputer dan literasi informasi. Literasi komputer berkembang pada dekade 1980-an, ketika komputer mikro semakin luas dipergunakan, tidak saja di lingkungan bisnis, tetapi juga di masyarakat. Namun, literasi informasi baru menyebar luas pada dekade 1990-an manakala informasi semakin mudah disusun, diakses, disebarluaskan melalui teknologi informasi berjejaring”. Dengan demikian, mengacu pada pendapat Bawden, literasi digital lebih banyak dikaitkan dengan keterampilan teknis mengakses, merangkai, memahami, 
dan menyebarluaskan informasi. Terkait informasi yang diterima oleh peserta didik, perlu adanya pendekatan budaya dalam pembelajaran untuk memfilter informasi yang diterima (Darwanto et al, 2020)

Sementara itu, Douglas A.J. Belshaw dalam tesisnya What is 'Digital Literacy“? (2011) mengatakan bahwa "ada delapan elemen esensial untuk mengembangkan literasi digital, yaitu sebagai berikut.

- Kultural, yaitu pemahaman ragam konteks pengguna dunia digital;

- Kognitif, yaitu daya pikir dalam menilai konten;

- Konstruktif, yaitu reka cipta sesuatu yang ahli dan aktual;

- Komunikatif, yaitu memahami kinerja jejaring dan komunikasi di dunia digital;

- Kepercayaan diri yang bertanggung jawab;

- Kreatif, melakukan hal baru dengan cara baru;

- Kritis dalam menyikapi konten";

\section{Literasi Digital Dalam Pembelajaran Daring}

Kemampuan literasi digital mempunyai peranan yang cukup penting dalam pembelajaran termasuk dalam pembelajaran daring. Penelitian yang dilakukan oleh Azmi (2006) menyebutkan bahwa "keterampilan mencari informasi di database dianggap mahasiswa sebagai salah satu keterampilan penting yang harus dimiliki mahasiswa karena berperan penting menentukan keberhasilan studi. Oleh karena itu mahasiswa dengan kemampuan literasi digital yang baik akan berupaya untuk mencari dan menyeleksi informasi yang penting dan memahami, mengkomunikasikan, dan menyampaikan gagasan-gasan dalam ruang digital.

Sejalan dengan penelitian yang dilakukan oleh Azmi, beberapa penelitian lain menyebutkan bahwa kemampuan literasi digital akan membuka kesempatan kepada mahasiswa untuk berpikir, berkomunikasi, dan berkarya yang akhirnya bermuara pada kesuksesan belajar mahasiswa (Sujana \& Rachmatin, 2019) (Elpira, 2018). Oleh karena itu kesadaran akan urgensi kemampuan literasi digital perlu ditingkatkan baik dikalangan pengambil keputusan.

Kajian yang dilakukan oleh Dinata (2021) menyebutkan bahwa beberapa hal yang dapat dilakukan oleh pimpinan suatu institusi baik sekolah atau perguruan tinggi terkait pengembangan kemampuan literasi digital. Hal-hal yang dapat dilakukan yaitu 1) pelatihan literasi digital; 2) penanaman budaya literasi digital kampus; 3) membentuk tim penggerak literasi digital kampus. 


\section{B. Kesimpulan}

\author{
Kemampuan literasi digital \\ berperan penting dalam menunjang
} keberhasilan pembelajaran daring. mahasiswa dengan kemampuan literasi digital yang baik akan berupaya untuk mencari dan menyeleksi informasi yang penting dan memahami, mengkomunikasikan, dan menyampaikan gagasan-gasan dalam ruang digital. Selain itu, kemampuan literasi digital akan membuka kesempatan kepada mahasiswa untuk berpikir, berkomunikasi, dan berkarya yang akhirnya bermuara pada kesuksesan belajar mahasiswa

\section{DAFTAR RUJUKAN}

\section{JURNAL}

Dinata, K. B. (2019). Problematika Membangun Pemahaman Konsep Geometri Transformasi Mahasiswa Pendidikan Matematika di Universitas Muhammadiyah Kotabumi Tahun Akademik 2019/2020. Eksponen, 9(2), 01-09.

Dinata, K. B. (2018). Inovasi Pembelajaran Aljabar Ring Melalui Lesson Study. Eksponen, 8(1), 53-59.

Gagne, R.M, (1977). The Conditions of Learning, New York: Holt, Renehart and Winston.

Ratumanan, T.G. 2004. Belajar dan Pembelajaran. Edisi ke-2. Surabaya: Unesa University Press.

Kuntarto, E. (2017). Keefektifan model pembelajaran daring dalam perkuliahan bahasa Indonesia di perguruan tinggi. Indonesian Language Education and Literature, 3(1), 99110.

Dinata, K. B. (2020). Problematika Pembelajaran Daring Mata Kuliah Geometri Transformasi di Masa Pandemi Covid-19. Eksponen, 10(2), 50-58.

Hardini dan Puspitasari. 2012. Strategi Pembelajaran Terpadu. Yogyakarta: Familia.

Dinata, K. B., \& Darwanto, D. (2020). Pengembangan Bahan Ajar Peluang Dengan Pendekatan Kontekstual Berorientasi Pada Kemampuan Penalaran Dan Disposisi Matematis Berbasis Android. Eksponen, 10(1), 1-10.

Putria, H., Maula, L. H., \& Uswatun, D. A. (2020). Analisis proses pembelajaran dalam jaringan (daring) masa pandemi covid-19 pada guru sekolah dasar. Jurnal Basicedu, 4(4), 861-870. 
Pangondian, R. A., Santosa, P. I., \& Nugroho, E. (2019, February). Faktor-faktor yang mempengaruhi kesuksesan pembelajaran daring dalam revolusi industri 4.0. In Seminar Nasional Teknologi Komputer \& Sains (SAINTEKS) (Vol. 1, No. 1).

Risdianto, E. (2019). Analisis pendidikan indonesia di era revolusi industri 4.0. April, 0-16. Diakses pada, 22.

Bawden, D. (2001). Information and digital literacies: a review of concepts. Journal of documentation.

Dinata, K. B. (2020). Pengintegrasian Budaya Lampung dalam Pembelajaran Mata Kuliah Himpunan Dengan Flatform Schoology. JUMLAHKU: Jurnal Matematika Ilmiah STKIP Muhammadiyah Kuningan, 6(2), 126-136.

Azmi, H. (2006). Innovation in Teaching and Learning in Information and Computer Sciences: Teaching Information Literacy Skills: A case study of the QU-core program in Qatar Universit. Learning in Information and Computer Sciences, 5(4), 145-164.

Elpira, B. (2018). Pengaruh penerapan literasi digital terhadap peningkatan pembelajaran siswa di smp negeri 6 banda aceh (Doctoral dissertation, UIN Ar-Raniry Banda Aceh).

Dinataa, K. B. (2019). Pengaruh Model Pembelajaran Kooperatif Tipe Jigsaw Dengan Pendekatan Pmr Terhadap Aspek Afektif Matematika Siswa Kelas VII SMP Negeri Di Kabupaten Lampung Utara. Eksponen, 9(1), 1-7.

Sujana, A., \& Rachmatin, D. (2019). Literasi digital abad 21 bagi mahasiswa PGSD: apa, mengapa, dan bagaimana. In Current Research in Education: Conference Series Journal (Vol. 1, No. 1, 003-013

Dinata \& Darwanto. 2021. Urgensi Kemampuan Literasi Digital dalam Pembelajaran Daring. Implementasi Mardeka Belajar Di Masa Pandemi Covid 19: Peluang dan Tantangan (Prosiding). Bandar Lampung: 16 Februari 2021. Hal. 388-398.

\section{BUKU}

Kasali, R. (2018). Disruption (9th ed.). Jakarta: Gramedia.

Gilster, P., \& Watson, T. (1999). Digital literacy. New York. Wiley Computer Pub.

Belshaw, D. (2011). What is' digital literacy'. A pragmatic investigation. Durham, UK: Durham University. 